\title{
Climate change mitigation through increased biomass production and substitution: A case study in north-central Sweden
}

\author{
Bishnu Chandra Poudel $^{1, *}$, Roger Sathre ${ }^{1}$, Leif Gustavsson ${ }^{1,2}$, Johan Bergh ${ }^{1,3}$ \\ ${ }^{1}$ Ecotechnology, Mid Sweden University, Östersund, Sweden \\ ${ }^{2}$ Linnaeus University, Växjö, Sweden \\ ${ }^{3}$ Southern Swedish Forest Research Centre, Swedish University of Agricultural Sciences, Alnarp, Sweden \\ *Corresponding author. Tel: +4663165535, E-mail: bishnu.poudel@miun.se
}

\begin{abstract}
In this study, we perform an integrated analysis to calculate the potential increases in forest biomass production and substitution as an effect of climate change and intensive management. We use the BIOMASS model to simulate change in Net Primary Production due to climate change. Then we estimate the development of forest biomass growth and harvest by using the HUGIN model, the change in soil carbon stock by the use of the Q-model, and the biomass substitution benefits by the use of an energy and material substitution model. Our results show that an average regional temperature rise of $4{ }^{\circ} \mathrm{C}$ could increase annual whole tree forest biomass production by $32 \%$ and harvest by $29 \%$ over the next 100 years. Intensive forest management including climate effect could increase whole tree biomass production by $58 \%$ and harvest by $47 \%$. A total net reduction in carbon emissions of up to $89 \mathrm{Tg} \mathrm{C}$ and $182 \mathrm{Tg} \mathrm{C}$ over 100 years is possible due to climate change effect only and due to climate change plus intensive forestry, respectively. The carbon stock in standing biomass, forest soils and wood products all increase, but the carbon stock changes are less significant than the substitution benefits.
\end{abstract}

Keywords: Forest biomass, Carbon, Bioenergy, Construction material, Intensive forestry

\section{Introduction}

Increasing atmospheric concentration of greenhouse gases (GHGs) increase earth's surface temperature [1]. The Intergovernmental Panel on Climate Change (IPCC) [2] affirms that the temperature increase will be greater in the higher latitudes. The regional climate model by the Swedish Meteorological and Hydrological Institute (SMHI) [3] based on IPCC B2 scenario projects a $4{ }^{\circ} \mathrm{C}$ average temperature increase in north-central Sweden in the next 100 years.

The increasing temperature has significant impact on physical systems. It provides a longer growing season for the trees and favorable conditions for photosynthesis that stimulates Net Primary Production (NPP) [4]. Thus, an increased temperature is expected to produce more biomass in the boreal forests [5]. Although the boreal forest is considered as less productive due to low soil temperature and low nitrogen availability [6], production can further be increased by adding nutrients, by species change, and by changes in management practices [7, 8]. As a result, there will likely be larger harvest levels available in future.

The increased forest biomass can be used as a substitute for fossil fuels and carbon intensive materials to reduce carbon emissions through several mechanisms [9]. Using biomass to substitute for fossil fuels directly avoids fossil carbon emissions, except to the extent that fossil fuels are used to operate the biomass system [10]. Using biomass to substitute for carbon-intensive materials may reduce carbon emissions by lowering fossil energy use during the manufacture of products, by avoiding industrial processes emissions, by increasing carbon stocks in wood materials, by using biomass residues to replace fossil fuels, and possibly by carbon sequestration or emissions from wood products deposited in landfills [11, 12].

This paper describes an integrated assessment of the potential forest biomass increase as an effect of climate change and intensive forestry practices in north-central Sweden, and 
potential climate change mitigation with increased biomass use. Using five scenarios for forest production and two scenarios for biomass utilization, we estimate the increased biomass production, its harvest level, and carbon benefits from the substitution of non-wood materials and fossil fuels. We also estimate the carbon stock changes in standing biomass, soil, and wood products, and finally quantify the overall carbon balance for each scenario.

\section{Methodology}

\subsection{Study area}

This study considers Jämtland and Västernorrland, two counties in north-central Sweden. The area lies from $61^{\circ} 33^{\prime}$ to $65^{\circ} 07^{\prime} \mathrm{N}$ latitude and from $12^{\circ} 09^{\prime}$ to $19^{\circ} 18^{\prime} \mathrm{E}$ longitude. The forest land area is about 3.5 and 1.9 million ha, respectively. Of this area, productive forests ${ }^{1}$ excluding protected areas cover about 2.6 million ha and 1.7 million ha, respectively [13].

\subsection{Climate change}

IPCC Special Report on Emission Scenarios (SRES) [14] describes potential GHG emissions pathways during the 21st century based on the main driving forces of GHG emissions, considering their underlying uncertainties. Our regional climate scenarios are based on the IPCC B2 global scenario, corresponding to moderate emissions of GHGs leading to an atmospheric $\mathrm{CO}_{2}$ concentration of $572 \mathrm{ppm}$ by the year 2085, with model RCA3 (The Rossby Centre's regional Atmospheric model) that uses a grid of approximately $50 \mathrm{~km} \times 50 \mathrm{~km}$. The RCA3 model uses global driving variables from the general circulation model ECHAM4/OPYC3 [15] covering the period of 1961-2100. Climate projections for northcentral Sweden are for an increase in average annual temperature of $4{ }^{\circ} \mathrm{C}$ by 2100 [16].

\subsection{Scenarios}

We compare forest biomass production in a Reference scenario that assumes the current forest management practices without any climate change effect, and four scenarios that include climate change effect: Current, Environment, Production, and Maximum, (Table 1).

Table 1. Overview of scenarios analyzed in this study.

\begin{tabular}{llll}
\hline Scenario & Climate & Forest management goals & Biomass use \\
\hline Reference & No change & Reference (current management) & Stem wood or whole tree \\
Current & Change & Current management & Stem wood or whole tree \\
Environment & Change & Fulfill environmental goals & Stem wood or whole tree \\
Production & Change & Increase biomass production & Stem wood or whole tree \\
Maximum & Change & Maximize biomass production & Stem wood or whole tree \\
\hline
\end{tabular}

The Current scenario assumes a continuation of current forest management practices. The Environment scenario assumes the fulfillment of additional environmental goals, e.g. 8\% of total forest land is set aside for reserves, and $14 \%$ of total forest land is given special environmental care. The Production scenario uses additional silvicultural practices, e.g. improved genetic material plantation, soil scarification, selection of tree species, increased traditional fertilization and a balanced nutrient supply [8]. The Maximum scenario uses silvicultural practices to maximize the production by replacing of Scots pine with lodge-pole

\footnotetext{
${ }^{1}$ Non-productive forests are defined as forests with production capacity less than $1 \mathrm{~m}^{3}$ per ha and year.
} 
pine (Pinus contorta) and by adding balanced nutrient supply in young stands of lodge-pole pine and Norway spruce. The effect of a lower and higher precipitation is considered in the scenarios and had no significant effect on production in northern Sweden [4]. The scenarios are described in more detail in [17].

\subsection{Forest production modeling}

The process-based growth model BIOMASS describes the processes of radiation absorption, canopy photosynthesis, phenology, allocation of photosynthates among plant organs, litterfall, and stand water balance in a tree [18]. BIOMASS uses Swedish National Forest Inventory (NFI) database and current temperature for Reference scenario and increased temperature based on RCA3 climate model (see Section 2.2) for the estimation of NPP. Values of daily precipitation are used in NPP simulations. The parameterization is valid for mesic soils, and the effects of water deficits would be more pronounced on drier sites [7]. Water deficits seem to be at a low level in simulations, since extremely dry summers didn't occur in the data set, which could lead to substantial losses in production. Output data on NPP from the BIOMASS are used to determine the growth functions in the HUGIN model $[5,17]$ an empirical model for long-term forecasts of timber yield and harvest level [19]. It uses sample plots from NFI, defining initial conditions for the model in order to describe the forest conditions during the development of young stands, their establishment, and the sivicultural treatments. The growth simulators in HUGIN are valid for all forest land in Sweden, for all types of stands, with a wide range of management alternatives [19].

\subsection{Soil carbon modeling}

The Q-model describes changes in soil carbon stock based on litter inputs, soil temperature, and the decomposition of litter fractions [20]. It uses old carbon in the soil, litter inputs from standing trees, thinnings and harvests, and soil carbon from fine roots. The decomposition in response to temperature is calculated as in Ågren et al. [21] and Bosatta and Ågren [20]. For more details see [5].

\subsection{Biomass use modeling}

The harvested biomass in thinnings and final fellings is assumed to substitute non-wood materials and fossil fuels. In the "stem wood" option we assume that $95 \%$ of coniferous stem wood ( $>20 \mathrm{~cm}$ diameter) is harvested and used as construction material to replace reinforced concrete $[5,11,17]$. The small stems and processing residues of coniferous trees, and all deciduous stem wood, is used as biofuel. In the "whole tree" option, in addition to stem wood use, $75 \%$ of branches and tops, $25 \%$ of needles, and $50 \%$ of stumps are harvested and used as biofuel $[5,11,17]$. Biofuel is assumed to replace coal in stationary plants.

\subsection{Forest operations and fertilization}

We account for emissions from fossil fuels used for forest management activities including stand establishment, thinnings, final harvest of round wood, and forwarding and transport of round wood to mills [22]. GHG emissions associated with production and use of fertilizers include $\mathrm{CO}_{2}, \mathrm{~N}_{2} \mathrm{O}$ and $\mathrm{CH}_{4}$ and are converted to $\mathrm{CO}_{2}$ equivalent using global warming potentials (GWP) over a 100-year time horizon [1]. Primary energy use and GHG emissions for the production of Skog-CAN fertilizer (27-0-0) and Opti-Crop fertilizer (24-4-5) are based on Davis and Haglund [23]. The amount of fossil fuel used for fertilizer application by helicopter is based on Mead and Pimentel [24]. 


\section{Results and discussions}

\subsection{Forest biomass production and harvest}

Figure 1 shows the annual forest biomass production and harvest in all scenarios at the end of the study period. The annual whole tree biomass production in the Reference scenario is 12.8 $\mathrm{Tg}$ year ${ }^{-1}$ at the end of the study period compared to $11.0 \mathrm{Tg}_{\text {year }}{ }^{-1}$ in the beginning of the study, a $17 \%$ increase during the 100-year period. The corresponding increases for the Current, Environment, Production and Maximum scenarios are 49\%, 40\%, 53\%, and 75\%, respectively. Thus biomass production increases in the Current, Environment, Production and Maximum scenarios are respectively 32\%, 23\%, 36\% and 58\% greater compared to the Reference scenario increase. The whole tree harvest in the Current scenario increases by 31\% more and in the Maximum scenario by 50\% more than the Reference scenario. The increase in stem wood biomass production for the Maximum scenario is $57 \%$ greater and the harvest is $54 \%$ greater compared to the Reference scenario.

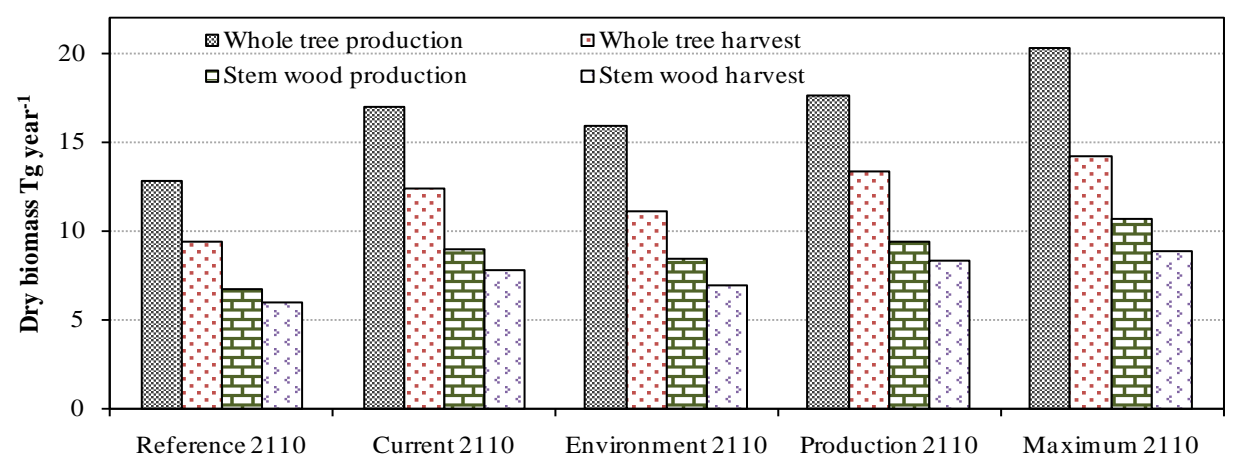

Fig. 1. Annual forest biomass production and harvest $\left(\right.$ Tg year $\left.^{-1}\right)$ in all scenarios at the end of the study period in Jämtland and Västernorrland.

Figure 2 shows the cumulative biomass harvest for all products in different scenarios during the 100 year. Stem wood is the largest fraction, while stumps are the second largest. The stump values might be slightly overestimated because of the Marklund's revised function [25] that estimates stump biomass based on spruce stumps which likely overestimates the deciduous tree stumps [5].

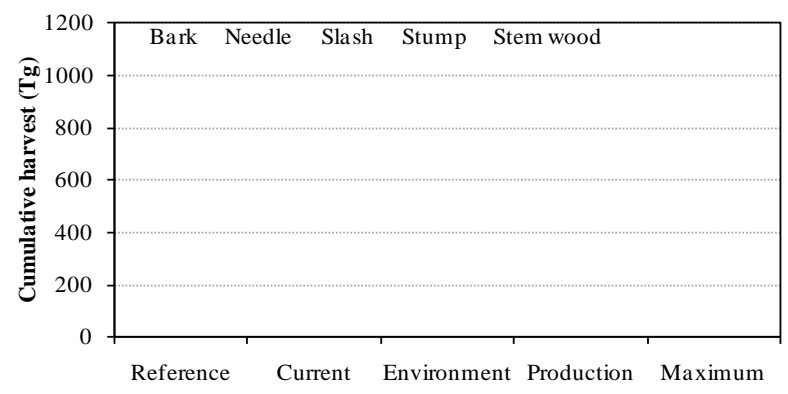

Fig. 2. Cumulative biomass harvest (Tg dry matter) for all products in the different scenarios during 100-years in Jämtland and Västersorrland.

The increased production in the Current scenario is caused by climate change, while in the other scenarios are the results of climate change plus intensive forestry practices such as species change, fertilization, and intensive silvicultural action [5]. 


\subsection{Carbon stock in standing biomass, forest soils, and wood products}

Annual carbon stocks in living tree biomass, soil and harvested wood products with whole tree harvest increase in all scenarios (Fig. 3). Maximum scenario has the largest carbon stock in forest biomass, followed in descending order by Environment, Production, Current and Reference scenarios. Maximum scenario has the largest soil carbon stock, followed by the Reference and Production scenarios. Caron stock increases slowly in the Environment and Current scenario after 30 years compared to the other scenarios (Fig. 3). Wood product carbon stock is also largest in Maximum scenario, followed by the Production and Current scenarios, while Environment and Reference have smaller. The larger carbon stock is due to larger volume of stem wood harvested and used as building materials, however, after the life span of buildings, the carbon stock may stabilize due to the demolition of old buildings [17].

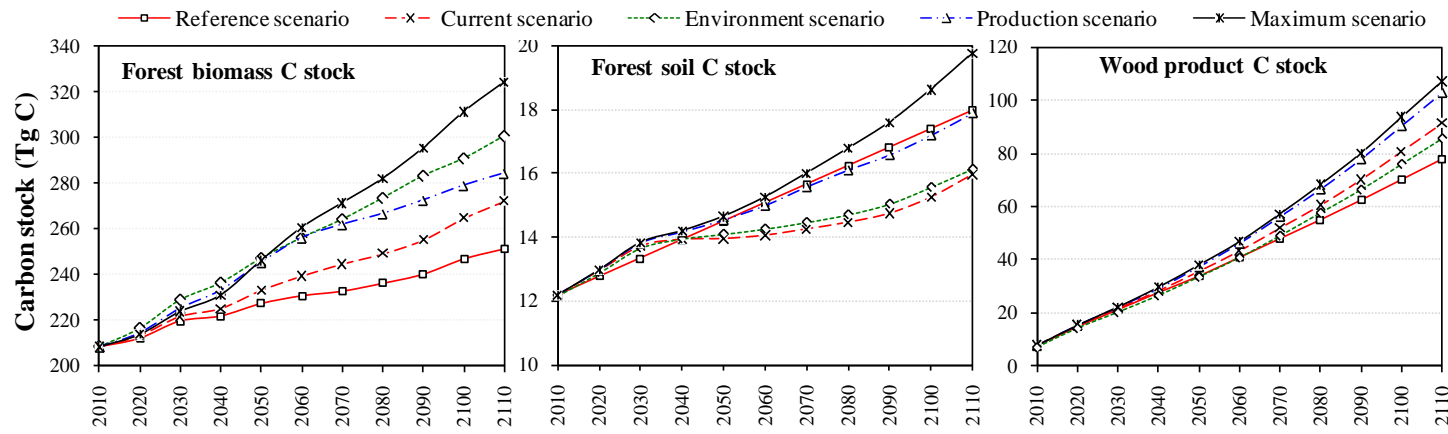

Fig. 3. Annual carbon stocks ( $\mathrm{Tg} C$ ) in living forest biomass, forest soil, and wood products in the different scenarios during 100-years in Jämtland and Västernorrland. Note differences in scale.

Table 2. Average annual avoided carbon emissions due to forest biomass use ( $\left.\operatorname{Tg} C y^{-1}\right)$ during each 10-year period for Jämtland and Västernorrland.

\begin{tabular}{|c|c|c|c|c|c|c|c|c|c|c|}
\hline & $\begin{array}{c}2010- \\
2019\end{array}$ & $\begin{array}{c}2020- \\
2029\end{array}$ & $\begin{array}{c}2030- \\
2039\end{array}$ & $\begin{array}{c}2040- \\
2049\end{array}$ & $\begin{array}{c}2050- \\
2059\end{array}$ & $\begin{array}{c}2060- \\
2069\end{array}$ & $\begin{array}{c}2070- \\
2079\end{array}$ & $\begin{array}{c}2080- \\
2089\end{array}$ & $\begin{array}{c}2090- \\
2099\end{array}$ & $\begin{array}{l}2100- \\
2109\end{array}$ \\
\hline \multicolumn{11}{|c|}{ Reference Scenario } \\
\hline Stem wood & 3.8 & 3.7 & 3.6 & 3.7 & 3.9 & 3.9 & 3.9 & 4.0 & 4.0 & 4.2 \\
\hline Whole tree & 4.9 & 4.7 & 4.8 & 4.8 & 5.1 & 5.1 & 5.0 & 5.1 & 5.1 & 5.4 \\
\hline \multicolumn{11}{|c|}{ Current Scenario } \\
\hline Stem wood & 3.9 & 3.8 & 3.8 & 3.9 & 4.3 & 4.4 & 4.7 & 4.7 & 5.1 & 5.6 \\
\hline Whole tree & 5.0 & 4.9 & 5.0 & 5.1 & 5.6 & 5.7 & 6.1 & 6.1 & 6.5 & 7.1 \\
\hline \multicolumn{11}{|c|}{ Environment Scenario } \\
\hline Stem wood & 3.6 & 3.6 & 3.6 & 3.7 & 4.0 & 4.1 & 4.3 & 4.5 & 4.8 & 5.0 \\
\hline Whole tree & 4.6 & 4.6 & 4.7 & 4.9 & 5.2 & 5.3 & 5.5 & 5.7 & 6.1 & 6.4 \\
\hline \multicolumn{11}{|c|}{ Production Scenario } \\
\hline Stem wood & 3.9 & 3.8 & 4.0 & 4.2 & 4.6 & 5.0 & 5.3 & 5.4 & 5.8 & 6.2 \\
\hline Whole tree & 4.9 & 5.0 & 5.2 & 5.5 & 6.0 & 6.4 & 6.7 & 6.8 & 7.3 & 7.8 \\
\hline \multicolumn{11}{|c|}{ Maximum Scenario } \\
\hline Stem wood & 3.9 & 3.9 & 4.1 & 4.3 & 4.7 & 5.0 & 5.5 & 5.7 & 6.0 & 6.6 \\
\hline Whole tree & 5.0 & 5.0 & 5.4 & 5.6 & 6.0 & 6.4 & 7.0 & 7.2 & 7.6 & 8.4 \\
\hline
\end{tabular}

\subsection{Biomass substitution}

Biomass substitution is largest in Maximum scenario (Table 2). The cumulative avoided carbon emission due to use of stem wood and whole tree biomass for Maximum scenario is 497 and 635 Tg C, respectively. As Maximum and Production scenarios have larger harvests, 
they will give larger substitution benefits. When compared to the Reference scenario, Maximum and Production scenarios give $136 \mathrm{Tg} \mathrm{C}$ and $116 \mathrm{Tg} \mathrm{C}$ greater benefits, while Environment and Current scenario have comparatively smaller substitution benefits.

\subsection{Carbon balance}

Cumulative avoided carbon emission over 100 years for all scenarios with the use of whole tree biomass is shown in Figure 4. Biomass substitution is the largest contributor to the carbon balance. The avoided carbon emission due to biomass substitution with recovered harvest slash and stumps is greater than the reduced increase in soil carbon stock in the forest due to harvest of whole tree biomass. The total avoided emissions in the Maximum and Production scenarios are $182 \mathrm{Tg} C$ and $117 \mathrm{Tg} C$ greater than in the Reference scenario over the 100-year period for whole tree biomass use. The corresponding numbers for the Environment and Current scenarios are 31 and $48 \mathrm{Tg}$ C, respectively.

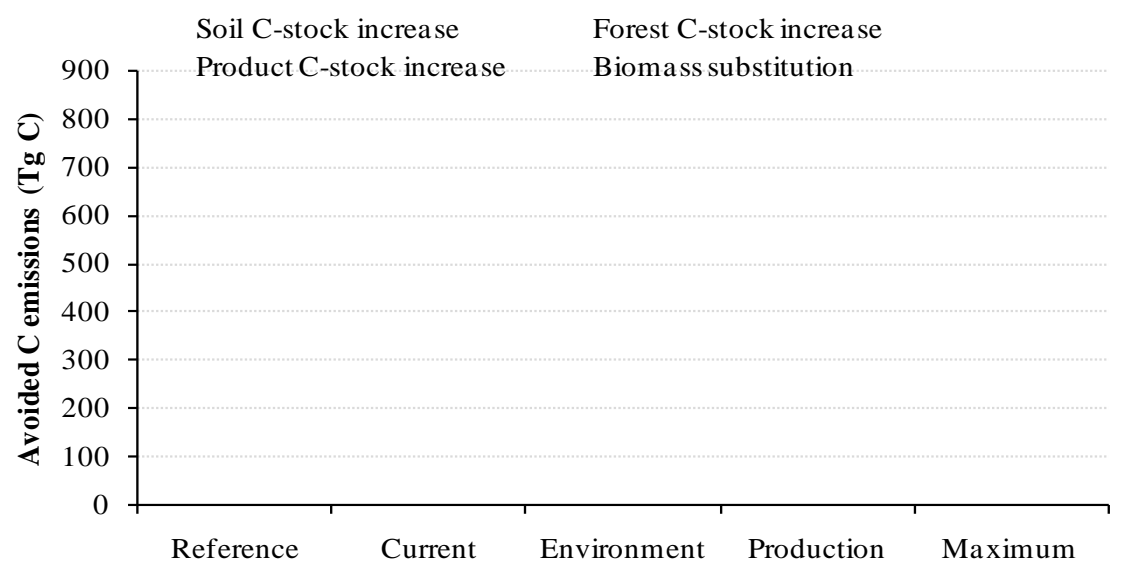

Fig. 4.Cumulative avoided carbon emissions ( $\mathrm{Tg} C)$ over 100- years for all scenarios with whole tree biomass use for Jämtland and Västernorrland.

\section{Conclusions}

Climate change may substantially increase the production of biomass in boreal forests. The production can be further increased by intensive forestry practices. The increased forest biomass, if used to substitute for fossil fuels and carbon intensive materials, can avoid carbon emissions, thus contributing to climate change mitigation. This is a negative feedback on climate change. The substitution potential depends on the amount and type of forest biomass harvest. Thus, larger biomass harvests create greater substitution potential.

In this study, significant uncertainties can be observed. Net increase of greenhouse gases, driving the temperature change, depends on several factors as the development of the global population, economic growth, and on mitigation actions to be taken. The results may vary somewhat with differences in the temperature and other corresponding variables. Regional temperature increases may differ from our assumptions. Fire risk, pathogens and insect damage which may cause tree mortalities are not accounted in our study. The HUGIN model overestimates biomass in deciduous living mature trees and stumps. HUGIN does not have a function to calculate self thinning in living deciduous trees, which may lead to an overestimation of biomass in Environment scenario. Nevertheless, although these uncertainties may alter the exact values that we have calculated, it appears that our general conclusions are robust. 


\section{Acknowledgement}

We gratefully acknowledge the support of European Union, County Administrative Board of Jämtland, Sveaskog AB, SCA Forest Products, Norrskog/SÅTAB, Jämtkraft AB. We also thank two anonymous reviewers for their comments.

\section{References}

[1] IPCC, Climate Change: The Physical Science Basis. Contribution of Working Group I to the Fourth Assessment Report of the Intergovernmental Panel on Climate Change, ed. S. Solomon, et al. 2007: Cambridge University Press, United Kingdom and New York, USA.

[2] IPCC, The Scientific Basis: Contribution of Working Group I to the Third Assessment Report of the Intergovernmental Panel on Climate Change. 2001, New York , USA: Cambridge University Press.

[3] SMHI. Climatic data, Swedish Meteorological and Hydrological Institute. 2009 [cited 2009 2, August]; Available from: http://www.smhi.se/cmp/jsp/polopoly.jsp?d=8785\&l=sv.

[4] Bergh, J., U. Nilsson, B. Kjartansson, and M. Karlsson, Impact of climate change on the productivity of Silver birch, Norway spruce and Scots pine stands in Sweden with economic implications for timber production., Eco.Bulletins, 53(15), 2010: pp. 185-195.

[5] Poudel, B.C., R. Sathre, L. Gustavsson, J. Bergh, A. Lundström, and R. Hyvönen, Effects of climate change on biomass production and substitution in north-central Sweden, Manuscript, 2010.

[6] Tamm, C.O., Nitrogen in terrestrial ecosystems, Ecological Studies, (81) 1991: pp. 1-115.

[7] Bergh, J., U. Nilsson, B. Kjartansson, and M. Karlsson, Impact of climate change on the productivity of Silver birch, Norway spruce and Scots pine stands in Sweden with economic implications for timber production., Ecological Bulletins, 53(15), 2010: pp. 185-195.

[8] Skogsstyrelsen, Skogliga konsekvensanalyser - SKA-VB 08 in Swedish Forest Agency Rapport. 2008, Skogsstyrelsen, Sweden.

[9] Schlamadinger, B., M. Apps, F. Bohlin, L. Gustavsson, G. Jungmeier, G. Marland, K. Pingoud, and I. Savolainen, Towards a standard methodology for greenhouse gas balances of bioenergy systems in comparison with fossil energy systems, Biomass and Bioenergy, 13(6), 1997: pp. 359-375.

[10] Hall, D.O. and J.I. House, Trees and biomass energy: Carbon storage and/or fossil fuel substitution?, Biomass and Bioenergy, 6(1-2), 1994: pp. 11-30.

[11] Gustavsson, L., K. Pingoud, and R. Sathre, Carbon dioxide balance of wood substitution: comparing concrete- and wood-framed buildings, Mitigation and Adaptation Strategies for Global Change, 11(3), 2006: pp. 667-691.

[12] IPCC, Climate Change: Mitigation of Climate Change. Contribution of Working Group III to the Fourth Assessment Report of the Intergovernmental Panel on Climate Change. 2007: Cambridge University Press, United Kingdom and New York, USA.

[13] Skogsstyrelsen. Forestry Statistics, Swedish Forest Agency. 2009 [cited 2009 2, August]; Available from: http://www.svo.se/episerver4/default.aspx?id=38515 
[14] IPCC, Special Report on Emissions Scenarios, in Emission Scenarios. Special Report of Working Group Ш of the Intergovernmental Panel on Climate Change. 2000, Cambridge University Press, UK.

[15] Kjellström, E., L. Bärring, S. Gollvik, U. Hansson, C. Jones, P. Samuelsson, M. Rummukainen, A. Ullerstig, Willén, and K. Wyser, A 140-year simulation of European climate with the new version of the Rossby Centre regional atmospheric climate model (RCA3), in SMHI Reports in Meteorology and Climatology, No. 108. 2006, SMHI: Norrköping, Sverige. pp. 54.

[16] SMHI. Climatic data, Swedish Meteorological and Hydrological Institute. 2009 [cited 2009, August, 2]; Available from: http://www.smhi.se/cmp/jsp/polopoly.jsp?d=8785\&l=sv.

[17] Poudel, B.C., R. Sathre, L. Gustavsson, J. Bergh, A. Lundström, and R. Hyvönen, Potential effects of intensive forestry on biomass production and substitution in northcentral Sweden, Manuscript, 2010.

[18] McMurtrie, R.E., D.A. Rook, and F.M. Kelliher, Modelling the yield of Pinus radiata on a site limited by water and nitrogen, Forest Ecology and Management, 30(1-4), 1990: pp. 381-413.

[19] Lundström, A. and U. Söderberg. Outline of the Hugin system for longterm forecasts of timber yields and possible cut. In Large-Scale Forestry Scenario Models: experiences and requirements. 1996: EFI proceeding.pp. 63-77

[20] Bosatta, E. and G.I. Ågren, Theoretical analyses of carbon and nutrient dynamics in soil profiles, Soil Biology and Biochemistry, 28(10-11), 1996: pp. 1523-1531.

[21] Ågren, G., R. Hyvönen, and T. Nilsson, Are Swedish forest soils sinks or sources for $\mathrm{CO}_{2}$-model analyses based on forest inventory data, Biogeochemistry, 82(3), 2007: pp. 217-227.

[22] Berg, S. and E.-L. Lindholm, Energy use and environmental impacts of forest operations in Sweden, Journal of Cleaner Production, 13(1), 2005: pp. 33-42.

[23] Davis, J. and C. Haglund, Life cycle inventory (LCI) of fertiliser production - Fertiliser products used in Sweden and Western Europe, in SIK Report No. 654, SIK. 1999, The Swedish Institute for Food and Biotechnology Göteborg, Sweden.

[24] Mead, D.J. and D. Pimentel, Use of energy analyses in silvicultural decision-making, Biomass and Bioenergy, 30(4), 2006: pp. 357-362.

[25] Pettersson, H. and G. Ståhl, Functions for belowground biomass of Pinus sylvestris, Picea abies, Betula pendula and Betula pubescens in Sweden, Scandinavian Journal of Forest Research, (21) 2006: pp. 84-93. 